UDC 811.111 '42

DOI https://doi.org/10.32838/2663-6069/2020.1-2/03

Baybakova I. M.

Lviv Polytechnic National University

Hasko O. L.

Lviv Polytechnic National University

\title{
IMITATIONAL AND ROLE-PLAY STRATEGIES IN THE ESP DISCOURSE TRAINING
}

The article is aimed at focusing on ESP discourse training with regard to imitational and roleplay strategies treated as versatile and effective educational techniques applied for simulation of real-life situations making professional language acquisition process natural and meaningful. Being widely used in General English learning/teaching process, imitational and role-play strategies can also be quite successful in ESP discourse training. By engaging a group of students and making them active and dynamic participants in the course of studies, role-play increases their motivation, develops team-work, creates relaxed atmosphere for simulating and practicing professionallyoriented and job-related activities. Since imitation and role-play are applied in different professional contents and contexts adjusted to the learners'future career, they enhance the would-be specialists' competitiveness in the job market.

Thus, imitation and role-play strategies can be successfully applied in the process of ESP discourse training for modelling the following real life activities and situations with the defined or free-choice roles: meeting conducted according to the agenda containing job-related issues; negotiations; job interview; mini-conference; professionally-oriented discussion engaging critical thinking, appropriate argumentation and proper rhetoric skills for two teams arguing on advantages and disadvantages of some disputable problems etc.

Belonging to the effective educational techniques applied in the process of ESP discourse training, imitational and role-play strategies serve as creative, practical and meaningful component of the preparatory stage for the would-be specialists'successful functioning within their professional environment. Focused on the target audience and its goal-directed feedback they considerably enhance the development of critical thinking by refining the quality of thought and argumentation in the framework of ESP discourse based on the tasks which resemble genuine situations related to students' professional field.

Key words: imitational and role-play strategies, educational techniques, ESP discourse training, simulation of real-life situations, professional environment.

Stating the problem. Being widely used in General English learning/teaching process, imitational and roleplay strategies can also be quite successful in ESP discourse training. By engaging a group of students and making them active and dynamic participants in the course of studies, role-play increases theirmotivation, develops team-work, creates relaxed atmosphere for simulating and practicing professionally-oriented and job-related activities. Since imitation and roleplay are applied in different professional contents and contexts they enhance the would be specialists' competitiveness in the job market.

Stating the task. The article is aimed at focusing on ESP discourse training with regard to imitational and role-play strategies treated as versatile and effective educational techniques applied for simulation of real-life situations making professional language acquisition process natural and meaningful.

Analysis of the research and publications on the issue under consideration. According to Mark Nielsen (University of Queensland) imitation and play being "critical developmental domains in the evolution of human culture represent a foundation upon which human culture flourish' [7, p. 170, 177]. In his article 'Imitation, Pretend Play, and Childhood: Essential Elements in the Evolution of Human Culture?' he treats pretend play as a 'springboard for innovation' enabling human cultural mind 'to adapt to innumerable skills, actions, behaviors, and objects, some of which will be entirely arbitrary' [7, p. 177].

Role play is the act of imitating the character and behaviour of someone who is different from 
yourself, for example as a training exercise. Group members have to communicate with each other through role-play [3]. H. Komorowska [5] notices that role plays are activities which engage a group of people. Each of the participants has his own task to do. Tasks are written down on specially prepared cards and only card possessors know what is on their cards. Only then can the participants be sure that the activity is held out spontaneously. J. Edge [4] points out that role plays are built into English language teaching from the earliest stages, when students are asked to say the lines of a dialogue. Having this in mind, teachers can make better use of dialogues and not let students simply read the lines aloud. Students have to speak a dialogue and look at the person they are addressing. G. P. Ladousse $[6$, p. 5] presents it in a more descriptive way: When students assume a 'role', they play a part (either their own or somebody else's) in a specific situation. 'Play' means that the role is taken on in a safe environment in which students are as inventive and playful as possible.

The main body. Language is an omnipresent tool created by human and used by the television, the press, the internet and other means of public communication. It is obviously used by an average person in every day communication. There are potential problem areas which can occur when teaching languages and using skills. We will try to show how varied and vast is the way of teaching and learning English in accordance to role plays.

There are many different types of role plays. The choice of role plays that are to be used while learning belongs to the teacher. D. Byrne [2] gives two basic types of role plays. First of them allows students to play themselves in an imaginary situation. There is no need for them to take the role of a totally different person. The situation itself is also realistic and can occur in everyday life, whereas in the second type of role plays students can be asked to play imaginary people in an imaginary situation.

It has to be said that the first type of role plays mentioned above is more useful for students because they are likely to find themselves in such situations.

D. Byrne [2] gives a different division of role plays which is based on open-ended dialogues, mapped dialogues, role instructions and scenarios. Openended dialogues let the students decide how they are going to develop them. This kind of dialogue is a kind of frame or skeleton. Needless to say, some things are already done or stated but some have to be developed further. Students have here some fundamentals and they only have to finish building the whole. It is worth stressing the fact that this type of role play is suitable for the students at the elementary or intermediate levels because students at this stage in foreign language learning do not have to produce entire sentences and role plays on their own.

Mapped dialogues are more sophisticated than open-ended dialogues because in this type the students are given only some functional cues and they have to provide all the language for themselves. This task is more complicated but the satisfaction after well conducted role play is greater than in the previous type. Students have before mentioned functional cues on their cards and there is an information gap between them. Of course the speakers will be eager to bridge this information gap [2].

Role instructions are also good for setting up role plays especially since the instructions can be very simple. This type of exercise describes the situation and tells the participants how they should interact.

Finally, there are scenarios which outline the sequence of events. They can be about everyday situations as well as imaginary situations. This kind of activity encourages students to practice functions such as asking for and giving information, asking for permission and apologizing. It should be remembered that at the same time students have great fun.

Role plays can be also divided into those which are good for training interpersonal skills, communication skills, conflict resolution, developing insights and group decision making as shown on the diagram below [9].

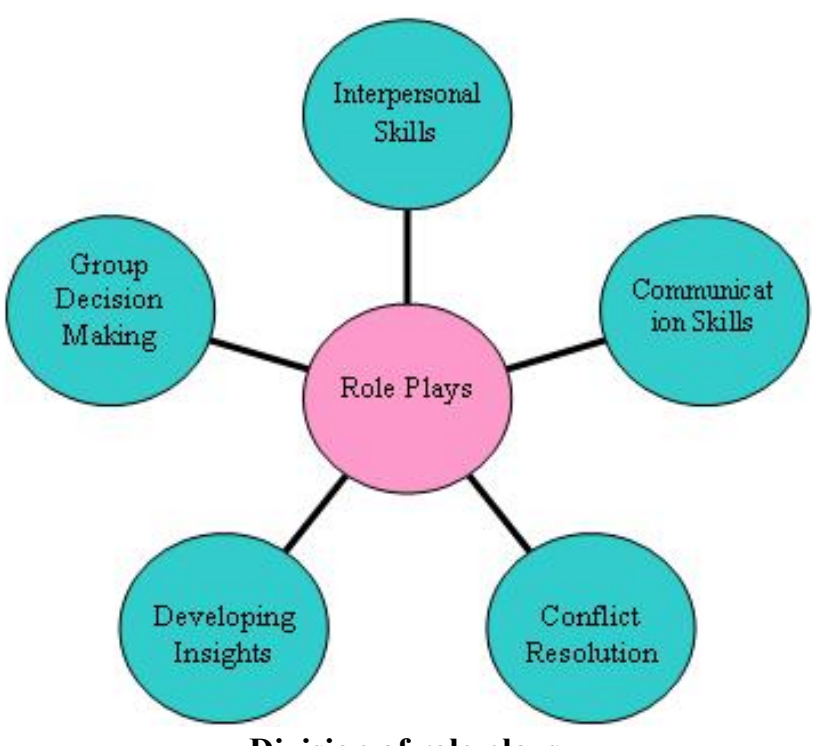

Division of role plays

One of the important foci of interest is introducing classroom management while working with role plays. As is well known, group work activities can lead to 
chaos if the students are not properly monitored. The most important thing to remember during group work activities is stating the rules clearly before the activity begins and this will help the teacher to conduct a lesson successfully. G. P. Ladousse provides basic principles that have to be present when setting up a role play "distinguishing between noise and chaos" [6, p. 12]. It is important to remember that during group or pair work activities students behave louder than usually but this loudness cannot disturb the teacher next door. If the teacher next door complains it can be said that there is too much chaos in the classroom where role plays are taking place. Another crucial rule when launching role plays is "beginning with pair work rather than group work" [6, p. 12]. G. P. Ladousse [6] claims that it is easier to talk to one person than to a group of people. Students can feel more secure when they are in direct one-to-one communication and they are less self-conscious. With a lower amount of stress students' results can be better and it will encourage them to do the same task again. It is also suggested that teachers should "keep the activity short until students get used to it" [6, p. 12]. It is vital because when the teaching methods and materials are used too often and for a long time, they lose on their usefulness. Students need to be exposed to something for a short period of time because when there is too much of reading, listening or acting out role plays students are bored and the lesson is not effective. Changing activities frequently will grasp students' attention and make them focus on the task.

An alternative point to remember is that it is advisable to "make sure that a role play can be used with different numbers of students" [6, p. 12]. There is always a possibility that some students may be sick and they will normally be absent during classes. As a result, role plays have to be prepared for different numbers of students. Preparing teaching materials means to be flexible and be prepared for every situation.

Not a single task could be done without understanding what this task is about. The teacher has to ask students for feedback on what they have understood they have to do. Many times students misunderstand the teacher's commands and it is always of vital importance to ask them if everything is clear and sometimes to explain the task again.

It happens many times that a small group of students may destroy the order in the classroom. Sometimes it is better to ignore the students who are not participating in the lesson for the sake of other students acquiring knowledge.

J. Brophy [1] gives certain examples on how to increase motivation in a language classroom.
He enumerates such things as building a learning community, making yourself and your classroom attractive to the students, being an authoritative manager and socializer of students, using appealing communication practices.

The last but not least point is that strict time limit has to be set and the teachers as well as the students have to make every attempt to stick to it. Time limit is important because when it is set everything is organized and students know when they have to start and finish an assignment. Time limits force students to think faster, on the spot. It should be said that without any rules, role play activities would not be effective because students have to be aware of what they are supposed to do and how it is going to look like. Activities in which students are not told what and how to do something are generally failures.

Maria Asuncion Rojas and Jhonny Villafuerte in their paper 'The Influence of Implementing Roleplay as an Educational Technique on EFL Speaking Development' regard Role-play as one of the effective educational techniques in the English classroom environment in terms of Task-Based Learning (TBLT), Cooperative Learning (CL), Communicative Learning Teaching (CLT), and English for Specific Purposes (ESP). They state that Role-play being a positive complement to the English speaking development 'exposes learners to experience in genuine situations to strengthen learners' abilities for communicating naturally and meaningfully with their peers about events of their daily routines and future professional environment' $[8$, p. 726]. Dwelling on the contribution of Pole-play for students' speaking skills the authors point out students' communication skills improvement as well as learning environment improvement. As for ESP classes that implement Roleplay, they enable students 'to function appropriately in genuine situations that relate to the specific purpose of the learners' career' [8, p. 730] making them competitive in the job market. Thus, proving that Role-play can be applied using different contents and contexts the authors come to conclusion that it is a "versatile teaching technique in which the learner is a dynamic member of his knowledge acquisition process' $[8$, p. 728,730$]$.

Referring to imitation and Role-play advantages, besides the above mentioned ones, it is necessary to indicate the development of critical thinking by improving the quality of thought and argumentation in the course of practicing English in a realistic way through the completion of tasks which resemble genuine situations related to students' professional field. Creating appropriate, free of rivalry and friendly 
learning environment for simulation of real-life situations related to the learners' future professional activities makes the language acquisition process natural and meaningful. The reason why some teachers are reluctant to apply Role-play, is the chaos and disorder in the classroom caused by noise, laughter and shouting during the preparatory stage. Nevertheless, it is worth remembering that this form of educational activity provides 'constructive and goal-directed feedback' [8, p. 728].

Thus, imitation and role-play strategies can be successfully applied in the process of ESP discourse training for modelling the following real life activities and situations:

- meeting conducted according to the agenda containing job-related issues (chairperson and participants with the free-choice roles);

- negotiations (two or more Parties taking part in the talks related to the sphere of students' professional field);

- job interview (interviewer and several applicants);
- mini-conference (chairperson and participants including honorary guests, prominent scientists, leading specialists, Heads of corporations, representatives of different firms etc.);

- professionally-oriented discussion engaging critical thinking, appropriate argumentation and proper rhetoric skills for two teams arguing on advantages and disadvantages of some disputable problem.

Conclusions. Belonging to the effective educational techniques applied in the process of ESP discourse training, imitational and role-play strategies serve as creative, practical and meaningful component of the preparatory stage for the would be specialists' successful functioning within their professional environment. Focused on the target audience and its goal-directed feedback they considerably enhance the development of critical thinking by refining the quality of thought and argumentation in the framework of ESP discourse based on the tasks which resemble genuine situations related to students' professional field.

\section{References:}

1. Brophy J. Teaching and Learning History in Elementary Schools. 1997.

2. Byrne D. Teaching writing skills. Longman, N.Y., 1997. 154 p.

3. Collins English Dictionary. URL: https://www.collinsdictionary.com>dictionary>english $>$ role-play

4. Edge J. Essentials of English Language Teaching. Longman, N.Y., 1993. 160 p.

5. Komorowska H. Metodyka nauczania języków obcych. Fraszka edukacyjna. Warszawa, 2005. 272 p.

6. Ladousse G. P. Role play. OUP, Oxford, 1987. 181 p.

7. Nielsen Mark. Imitation, Pretend Play, and Childhood: Essential Elements in the Evolution of Human Culture? Journal of Comparative Psychology. 2012. Vol. 126. № 2. P. 170-181.

8. Rojas M. A., Villafuerte Jh. The Influence of Implementing Role-play as an Educational Technique on EFL Speaking Development. URL: http://www.academypublication.com/ojs/index.php/tpls/article/view/ tpls0807726732

9. URL: http://traininganddevelopment.naukrihub.com/methods-of-training/games-and-simulations/roleplays.html

\section{Байбакова І. М., Гасько О. Л. ІМІТАЦІЙНІ ТА РОЛЬОВІ СТРАТЕГІЇ ПРИ ВИВЧЕННІ АНГЛОМОВНОГО ДИСКУРСУ ФАХОВОГО СПРЯМУВАННЯ}

Статтю присвячено вивченню англомовного дискурсу фахового спрямування з використанням імітаиійних та рольових стратегій, які трактуються як універсальні та ефективні навчальні прийоми, щуо застосовуються для моделювання реальних життєвих ситуацій і набуття ознак натуральності та змістовності під час вивчення професійної мови. Шляхом залучення групи студентів рольові стратегії підвищують мотивацію, розвивають навички командної роботи, створюють сприятливу атмосферу для моделювання та практичного застосування професійно-орієнтованих видів діяльності, роблячи студентів творчими й активними учасниками навчального процесу. Оскільки імітаційні та рольові стратегії використовуються в різних професійних контекстах, їх наповнення відповідає майбутній кар'єрі студентів, результатом чого є підвищення їх подальшої конкурентоспроможності на ринку прачі.

Імітаційні та рольові стратегії можуть успішно застосовуватись під час вивчення англомовного фахового дискурсу для моделювання таких видів діяльності та реальних життєвих ситуачій з визначеними чи вільно вибраними ролями: збори з робочими питаннями на порядку денному; переговори; співбесіда у пошуках прачі; міні-конференщія; професійно орієнтована дискусія для двох команд щодо переваг і недоліків певних дискусійних проблем із застосуванням критичного мислення, відповідної аргументачії та належних риторичних навичок тощо. 
Завдяки тому, що імітаційні та рольові стратегії належать до ефективних навчальних прийомів, вони можуть успішно використовуватись у прочесі вивчення англомовного дискурсу фахового спрямування як творча, практична і змістовна складова частина підготовчого етапу для успішного функиіонування майбутніх спеціалістів у їх професійному середовищі. Крім того, маючи за основу професійно орієнтовані завдання та ситуації, розглянуті стратегії зосереджені на цільовій аудиторії та відповідному зворотному зв 'язку, що у свою чергу сприяє значному розвитку критичного мислення, вдосконалює якість думки та аргументачї̈ в контексті англомовного дискурсу фахового спрямування.

Ключові слова: імітаційні та рольові стратегії, навчальні прийоми, вивчення англомовного дискурсу фахового спрямування, моделювання реальних життєвих ситуаиій, професійне середовище. 